\title{
HUBUNGAN USIA, PARITAS IBU DAN USIA AYAH DENGAN KEJADIAN ANAK SINDROM DOWN DI SLB NEGERI PELAMBUAN BANJARMASIN TAHUN 2019
}

\author{
Anggeriyane, Esme ${ }^{1}$ \\ ${ }^{1}$ Dosen Universitas Muhammadiyah Banjarmasin \\ Email: esmeanggeriyane@umbjm.ac.id
}

\begin{abstract}
INTISARI
Latar Belakang: Sindrom Down merupakan kelainan genetik trisomi yang terdapat tambahan kromosom pada kromosom 21 sehingga menyebabkan kelainan fisik dan gangguan tumbuh kembang anak. Hasil studi memaparkan insiden kelahiran anak Sindrom Down semakin meningkat di seluruh dunia.

Tujuan: Penelitian ini bertujuan untuk mengetahui hubungan usia, paritas ibu dan usia ayah dengan kejadian anak Sindrom Down.

Metode: Penelitian ini menggunakan desain survei analitik dengan Cross Sectional, teknik purposive sampling, jumlah populasi 161 dan sampel dari kekhususnan tunagrahita berjumlah 98 orang.

Hasil: Usia ibu pada kategori tidak berisiko (20-35 tahun) berjumlah 53 orang $(53,06 \%)$, Paritas ibu pada paritas berisiko $(1$ dan $\geq 4)$ berjumlah 61 orang $(62,24 \%)$, usia ayah pada kategori tidak berisiko (25-40 tahun) berjumlah 77 orang $(78,57 \%)$ dan kejadian Sindrom Down pada kategori bukan Sindrom Down (kelompok tunagrahita tanpa tanda klinis Sindrom Down) berjumlah 92 orang $(93,8 \%)$. Hasil uji korelasi Spearman Rank antara usia ibu dengan kejadian anak Sindrom Down dengan $p$ value 0,014, paritas ibu dengan $p$ value 0,267 dan usia ayah dengan $p$ value 0,192 .

Kesimpulan: Penelitian ini menunjukkan bahwa terdapat hubungan yang cukup lemah antara usia Ibu dengan kejadian Sindrom Down. Selanjutnya, tidak ada hubungan significant antara paritas Ibu dan usia ayah dengan kejadian sindrom down. Penelitian ini menyarankan agar calon orang tua (Suami dan Istri) dapat mempertimbangkan secara lebih hati-hati usia Ibu (Istri) sebelum menikah dan perencanaan kehamilan, disamping usia Ayah, dan Paritas Ibu.
\end{abstract}

Kata kunci : Paritas, Sindrom Down, Usia 


\section{PENDAHULUAN}

Kelahiran seorang anak merupakan dambaan oleh setiap orangtua. Anak merupakan potensi penerus cita-cita bangsa diharapkan menjadi generasi yang berkualitas. Namun pada kenyataannya, harapan bisa berbanding terbalik dengan kenyataan. Memiliki anak yang mengalami Sindrom Down bukan pilihan yang diinginkan setiap orangtua. Sejalan dengan pengalaman Rusmawarni saat diwawancarai oleh Koran Banjarmasinpost tahun 2017 menceritakan bahwa sebagai seorang ibu mengaku sempat down dan menangis setelah mengetahui anaknya terlahir dalam kondisi tersebut (Anonim, 2017).

World Health Organization (WHO), mengestimasikan terdapat 1 kejadian Sindrom Down per 1.000 kelahiran hingga 1 kejadian per 1.100 kelahiran di seluruh dunia. Setiap tahunnya, sekitar 3.000-5.000 anak lahir dengan kondisi ini. WHO memperkirakan ada 8 juta penderita Sindrom Down di seluruh dunia (Kemenkes RI, 2019).

Kasus Sindrom Down di Indonesia cenderung meningkat. Kasus Sindrom Down pada anak 24-59 bulan berdasarkan hasil Riset Kesehatan Dasar (Riskesdas) tahun 2010 sebesar $0,12 \%$, tahun 2013 sebesar $0,13 \%$ dan meningkat menjadi $0,21 \%$. Riskesdas tahun 2018 juga memaparkan Sindrom Down menyumbang kecacatan sejak lahir terbesar kedua $0,21 \%$ setelah minimal satu jenis cacat $0,41 \%$ (Kemenkes RI, 2019).

Sekolah Luar Biasa (SLB) memiliki klasifikasi khusus dalam mengikuti kegiatan belajar mengajar di sekolah. SLBA khusus untuk murid yang menyandang tunanetra, SLB-B khusus untuk tunarungu, SLB-C untuk tunagrahita, SLB-D untuk tunadaksa dan SLB-E untuk tunalaras. Menurut Pusat Data dan Statistik Pendidikan dan Kebudayaan tahun 2016 menggambarkan jumlah siswa SLB di Pulau Kalimantan dengan jenis ketunaan tertinggi adalah tunagrahita, peringkat pertama berada di Kalimantan Selatan dan khususnya kota Banjarmasin (Mufidati, 2017).

Usia ibu saat hamil mempengaruhi risiko melahirkan anak dengan Sindrom Down. Semakin meningkat usia ibu saat hamil maka semakin besar risiko kejadian Sindrom Down yaitu 1:1490, usia 40 tahun sekitar 1:106 dan usia 49 tahun sekitar 1:11 kelahiran. Namun, sekitar $80 \%$ anak lahir dari ibu yang berusia kurang dari 35 tahun yang merupakan kelompok usia subur (Irwanto, dkk, 2019). Hasil penelitian Rahmah (2014) memperkuat faktor lain yaitu usia ayah dapat berisiko mempengaruhi kejadian anak lahir dengan Sindrom Down. Kemungkinan tersebut karena salah satu keluarga memiliki resiko yang diturunkan pada suatu kelahiran. Sejalan dengan penelitian Anggeriyane, dkk (2014) menjelaskan usia reproduksi sehat adalah 20-35 tahun karena sistem reproduksi telah matang dan hormonhormon bekerja dengan baik. Berbanding terbalik dengan usia berisiko $\leq 20$ dan $\geq 35$ tahun.

Berdasarkan studi pendahuluan yang dilakukan peneliti pada bulan November 2019 di SLB Negeri Pelambuan Banjarmasin dengan melakukan wawancara kepada guru. Hasil yang didapatkan bahwa Kalimantan Selatan menduduki peringkat pertama jumlah Anak Berkebutuhan Khusus (ABK), SLB Pembina Pelambuan Banjarmasin adalah SLB yang memiliki siswa berkebutuhan khusus terbanyak di Kota Banjarmasin dan jumlah murid terbanyak adalah kelompok tunagrahita pada tahun 2019. Beliau memberikan informasi yang selama ini sering ditemukan kenyataannya bahwa anak dengan Sindrom Down kebanyakan dilahirkan bukan dari ibu yang berusia tua (berisiko tinggi) namun kebanyakan berasal dari ibu yang mengalami pernikahan dini, bukan anak pertama dan bukan dari suami yang sudah tua. Berdasarkan latarbelakang tersebut maka peneliti tertarik untuk mengeksplorasi hubungan antara usia, paritas ibu dan usia ayah dengan kejadian anak dengan Sindrom Down di SLB Negeri Pelambuan Banjarmasin. 


\section{METODE PENELITIAN}

Penelitian ini menggunakan desain survei analitik korelasional dengan pendekatan Cross Sectional bertujuan untuk memperoleh penjelasan tentang hubungan usia, paritas ibu dan usia ayah terhadap kejadian anak Sindrom Down di SLB Negeri Pelambuan Banjarmasin tahun 2019. Populasi penelitian adalah seluruh siswa yang bersekolah di SLB Negeri Pelambuan Banjarmasin sebanyak 161 orang dan sampel dari kekhususan kelompok tunagrahita berjumlah 98 orang. Tehnik pengambilan sampel dilakukan dengan cara Purposive sampling. Instrumen penelitian untuk variabel usia, paritas ibu, usia ayah dan kejadian anak Sindrom Down menggunakan studi dokumen sekolah pada aplikasi Data Pokok Pendidikan (Dapodik) tahun 2019 dan data dianalisis menggunakan uji Korelasi Spearman Rank.

Prinsip etik yang diperhatikan pada penelitian ini yaitu menghormati harkat dan martabat, memperhatikan kesejahteraan, keadilan kepada semua subyek dan informed consent.

\section{HASIL}

Usia ibu pada kejadian anak Sindrom Down di SLB Negeri Pelambuan Banjarmasin Tahun 2019

Tabel 1.1 Distribusi Frekuensi Responden berdasarkan Usia Ibu

\begin{tabular}{cccc}
\hline No & Usia Ibu & $\mathrm{n}$ & $\%$ \\
\hline 1 & Tidak Berisiko & 52 & 53,06 \\
\hline 2 & Resiko Rendah & 26 & 26,53 \\
\hline 3 & Resiko Tinggi & 20 & 20,41 \\
\hline & Jumlah & 98 & 100 \\
\hline
\end{tabular}

Tabel 1.1 menunjukan bahwa jumlah usia ibu terbanyak terdapat pada kategori usia tidak berisiko berjumlah 52 orang $(53,06 \%)$.
Paritas ibu dengan kejadian anak Sindrom Down di SLB Negeri Pelambuan Banjarmasin Tahun 2019

Tabel 1.2 Distribusi Frekuensi Responden Berdasarkan Paritas Ibu

\begin{tabular}{cccc}
\hline No & Paritas & $\mathrm{n}$ & $\%$ \\
\hline 1 & Tidak Berisiko & 37 & 37,76 \\
\hline 2 & Berisiko & 61 & 62,24 \\
\hline & Jumlah & 98 & 100 \\
\hline
\end{tabular}

Tabel 1.2 menunjukan bahwa jumlah responden berdasarkan paritas ibu terbanyak adalah paritas berisiko berjumlah 61 orang $(62,24 \%)$.

Usia ayah dengan kejadian anak Sindrom Down di SLB Negeri Pelambuan Banjarmasin Tahun 2019

Tabel 1.3 Distribusi Frekuensi Responden Berdasarkan Usia Ayah

\begin{tabular}{cccc}
\hline No & Usia Ayah & $\mathrm{n}$ & $\%$ \\
\hline 1 & Tidak Berisiko & 77 & 78,57 \\
\hline 2 & Berisiko Rendah & 3 & 3,06 \\
\hline 3 & Berisiko Tinggi & 18 & 18,37 \\
\hline & Jumlah & 98 & 100 \\
\hline
\end{tabular}

Tabel 1.3 menunjukan bahwa jumlah responden berdasarkan usia ayah terbanyak adalah tidak berisiko berjumlah 77 orang $(78,57 \%)$.

\section{Kejadian Anak Sindrom Down di SLB Negeri Pelambuan Banjarmasin}

Tabel 1.4 Distribusi Frekuensi Kejadian Anak dengan Sindrom Down

\begin{tabular}{cccc}
\hline No & $\begin{array}{c}\text { Kejadian Anak } \\
\text { Sindrom Down }\end{array}$ & $\mathrm{n}$ & $\%$ \\
\hline 1 & Sindrom Down & 6 & 6,2 \\
\hline 2 & $\begin{array}{c}\text { Bukan Sindrom } \\
\text { Down }\end{array}$ & 92 & 93,8 \\
\hline & Jumlah & 98 & 100 \\
\hline
\end{tabular}

Tabel 1.4 menunjukan bahwa jumlah responden terbanyak berdasarkan kejadian Sindrom Down adalah bukan Sindrom Down adalah 92 orang $(93,8 \%)$. Kejadian anak bukan Sindrom Down yang dimaksud adalah siswa kekhususan kelompok tunagrahita yang tidak memiliki tanda klinis seperti anak dengan Sindrom Down. 
Hubungan usia ibu dengan kejadian anak Sindrom Down di SLB Negeri Pelambuan Banjarmasin Tahun 2019

Tabel 1.5 Hubungan Usia Ibu dengan Kejadian Anak Sindrom Down

\begin{tabular}{ccccccc}
\hline & \multicolumn{6}{c}{ Kejadian Anak dengan Sindrom Down } \\
\cline { 2 - 7 } Usia Ibu & $\begin{array}{c}\text { Sindrom } \\
\text { Down }\end{array}$ & $\begin{array}{c}\text { Bukan } \\
\text { Sindrom } \\
\text { Down }\end{array}$ & Total \\
\cline { 2 - 7 } & $\mathrm{n}$ & $\%$ & $\mathrm{n}$ & $\%$ & $\mathrm{n}$ & $\%$ \\
\hline Tidak Berisiko & 1 & 1,02 & 51 & 52,04 & 52 & 53,06 \\
\hline Risiko Rendah & 1 & 1,02 & 25 & 25,51 & 26 & 26,53 \\
\hline Risiko Tinggi & 4 & 4,08 & 16 & 16,33 & 20 & 20,41 \\
\hline Jumlah & 6 & 6,12 & 92 & 93,88 & 98 & 100 \\
\hline Hasil analisis Uji Spearman Rank $=0,014$ & \\
\hline
\end{tabular}

Tabel 1.5 dapat diketahui bahwa usia ibu terbanyak yang memiliki anak dengan Sindrom Down yaitu usia ibu berisiko tinggi berjumlah 4 orang $(4,08 \%)$ dan usia ibu terbanyak yang memiliki anak bukan dengan sindrom down yaitu usia ibu tidak berisiko berjumlah 51 orang $(52,04 \%)$.

Hasil uji statistik dengan uji Spearman Rank diperoleh angka koefisien korelasi sebesar 0,247*. Artinya, tingkat kekuatan hubungan (korelasi) antara variabel usia ibu dengan kejadian anak Sindrom Down adalah sebesar 0,247 atau hubungan cukup lemah dengan korelasi bernilai signifikan pada angka signifikansi sebesar 0,05. Angka koefisien korelasi 0,247 bernilai positif sehingga hubungan kedua variabel tersebut bersifat searah sehingga semakin tinggi usia ibu maka semakin tinggi kejadian anak dengan Sindrom Down. Berdasarkan tabel diatas, diketahui nilai signifikansi atau Sig. (2-tailed) sebesar 0,014, karena nilai Sig. (2-tailed) 0,014 $<0,05$ maka Ho ditolak artinya ada hubungan yang cukup lemah antara variabel usia ibu dengan kejadian anak Sindrom Down di SLB Negeri Pelambuan Banjarmasin.

Hubungan paritas ibu dengan kejadian anak Sindrom Down di SLB Negeri Pelambuan Banjarmasin Tahun 2019

Tabel 1.6 Hubungan Paritas Ibu dengan Kejadian Anak Sindrom Down

\begin{tabular}{cccccccc}
\hline & \multicolumn{4}{c}{ Kejadian Anak dengan Sindrom Down } \\
\cline { 2 - 7 } Paritas & \multicolumn{3}{c}{ Sindrom Down } & \multicolumn{3}{c}{ Bukan Sindrom } & \multicolumn{2}{c}{ Total } \\
\cline { 2 - 7 } & & $\mathbf{n}$ & $\boldsymbol{\%}$ & $\mathbf{n}$ & $\boldsymbol{\%}$ & $\mathbf{n}$ & $\boldsymbol{\%}$ \\
\hline Tidak & 1 & 1,02 & 36 & 36,73 & 37 & 37,76 \\
\hline
\end{tabular}

Berisiko

\begin{tabular}{ccccccc}
\hline Berisiko & 5 & 5,10 & 56 & 57,14 & 61 & 62,24 \\
\hline Jumlah & 6 & 6,12 & 92 & 93,88 & 98 & 100 \\
\hline \multicolumn{7}{c}{ Hasil analisis Uji korelasi Spearman Rank $=0,267$} \\
\hline
\end{tabular}

Tabel 1.6 dapat diketahui paritas ibu terbanyak dengan kejadian anak dengan Sindrom Down pada paritas berisiko berjumlah 5 orang $(5,10 \%)$ dan paritas ibu terbanyak dengan kejadian anak bukan Sindrom Down pada berisiko berjumlah 56 orang $(57,14 \%)$.

Hasil uji statistik dengan uji Spearman Rank diperoleh angka koefisien korelasi sebesar 0,111. Artinya, tingkat kekuatan hubungan (korelasi) antara variabel usia ibu dengan kejadian anak Sindrom Down adalah sebesar 0,111 atau hubungan sangat lemah dengan korelasi bernilai signifikan pada angka signifikansi sebesar 0,05. Angka koefisien korelasi 0,111 bernilai positif sehingga hubungan kedua variabel tersebut bersifat searah sehingga semakin tinggi paritas ibu maka semakin tinggi kejadian anak dengan Sindrom Down. Berdasarkan tabel diatas, diketahui nilai signifikansi atau Sig. (2-tailed) sebesar 0,276, karena nilai Sig. (2-tailed) 0,276 > 0,05 maka Ho diterima artinya tidak ada hubungan yang signifikan antara variabel paritas ibu dengan kejadian anak Sindrom Down di SLB Negeri Pelambuan Banjarmasin.

\section{Hubungan usia ayah dengan kejadian anak Sindrom Down di SLB Negeri Pelambuan Banjarmasin}

Tabel 1.7 Hubungan Usia Ayah dengan Kejadian Anak Sindrom Down

\begin{tabular}{|c|c|c|c|c|c|c|}
\hline \multirow{3}{*}{ Usia Ayah } & \multicolumn{6}{|c|}{ Kejadian Anak dengan Sindrom Down } \\
\hline & \multicolumn{2}{|c|}{$\begin{array}{l}\text { Sindrom } \\
\text { Down }\end{array}$} & \multicolumn{2}{|c|}{$\begin{array}{c}\text { Bukan } \\
\text { Sindrom } \\
\text { Down }\end{array}$} & \multicolumn{2}{|c|}{ Total } \\
\hline & $\mathbf{n}$ & $\%$ & $\mathbf{n}$ & $\%$ & $\mathbf{n}$ & $\%$ \\
\hline Tidak Berisiko & 6 & 6,12 & 71 & 72,45 & 77 & 78,57 \\
\hline Berisiko Rendah & 0 & 0 & 3 & 3,06 & 3 & 3,06 \\
\hline Berisiko Tinggi & 0 & 0 & 18 & 18,37 & 18 & 18,37 \\
\hline Jumlah & 6 & 6,1 & 92 & 93,88 & 98 & 100 \\
\hline Hasil analisi & & la & 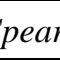 & $n R$ & $=$ & 192 \\
\hline
\end{tabular}

Tabel 1.7 dapat diketahui paritas responden terbanyak dengan kejadian anak dengan Sindrom Down pada usia ayah tidak berisiko berjumlah 6 orang $(6,12 \%)$ dan responden terbanyak dengan kejadian anak bukan 
Sindrom Down pada usia ayah tidak berisiko berjumlah 71 orang $(72,45 \%)$.

Hasil uji statistik dengan uji Spearman Rank diperoleh angka koefisien korelasi sebesar -0,133. Artinya, tingkat kekuatan hubungan (korelasi) antara variabel usia ibu dengan kejadian anak Sindrom Down adalah sebesar $-0,133$ atau hubungan sangat lemah dengan korelasi bernilai signifikan pada angka signifikansi sebesar 0,05. Angka koefisien korelasi $-0,133$ bernilai negatif sehingga hubungan kedua variabel tersebut bersifat tidak searah sehingga semakin tinggi usia ayah maka semakin rendah kejadian anak dengan Sindrom Down. Berdasarkan tabel diatas, diketahui nilai signifikansi atau Sig. (2tailed) sebesar 0,192, karena nilai Sig. (2tailed) 0,192>0,05 maka Ho diterima artinya tidak ada hubungan yang signifikan antara variabel usia ayah dengan kejadian anak Sindrom Down di SLB Negeri Pelambuan Banjarmasin.

\section{PEMBAHASAN}

\section{Hubungan usia ibu dengan kejadian anak sindrom down di di SLB Negeri Pelambuan Banjarmasin}

Hasil analisis Uji korelasi Spearman Rank menggunakan nilai Sig. (2-tailed) sebesar 0,014 pada $\alpha 5 \%$ dengan $\mathrm{N}=98$ sehingga $\mathrm{p}$ value $<0,05(0,014<0,05)$ maka Ho ditolak artinya ada hubungan yang cukup lemah antara variabel usia ibu dengan kejadian anak Sindrom Down di SLB Negeri Pelambuan Banjarmasin.

Sindrom Down adalah termasuk golongan penyakit genetik karena cacatnya terdapat pada bahan keturunan atau gen, tetapi penyakit ini pada dasarnya bukan penyakit keturunan atau yang diwariskan. Angka kejadian Sindrom Down rata-rata diseluruh dunia adalah 1 pada setiap 700 kelahiran. Kejadian ini akan bertambah dengan semakin tuanya usia ibu hamil. Biasanya calon bayi yang mengalami Sindrom Down akan gugur dengan persentase $60 \%$ dan lahir mati dengan persentase $20 \%$. Sindrom Down mempunyai jumlah kromosom 47, dimana terjadi penambahan pada kromosom 21 dengan jumlah 3 atau yang dikenal dengan trisomi sehingga Sindrom Down dikenal dengan nama trisomi 21 (Fadhli, 2010).
Usia ibu sangat mempengaruhi kematangan organ resproduksi wanita. Ketika seorang wanita hamil pada usia terlalu dini maka organ reproduksi belum matang sepenuhnya sedangkan pada usia tua maka organ reproduksi mulai mengalami penurunan. Menurut Astuti dan Ertiana (2018) menjelaskan usia ibu yang ideal dalam kehamilan adalah kelompok 20-35 tahun. Kelompok usia $<20$ tahun merupakan kelompok risiko rendah dan kelompok usia >35 tahun merupakan kelompok berisiko tinggi. Pada usia berisiko tinggi terjadi perubahan akibat penuaan organ sehingga kemungkinan untuk terkena penyakit dalam masa kehamilan yang berhubungan dengan usia semakin meningkat. Sejalan dengan hasil penelitian Rayman, dkk (2017) menyimpulkan terdapat hubungan antara usia ibu dengan kejadian anak dengan Sindrom Down. Usia ibu >35 tahun meningkatkan risiko untuk melahirkan 12 kali lebih besar dari usia ibu <35 tahun. Hal ini dijelaskan dalam uraian patogenesisnya yang diakibatkan penurunan fungsi organ reproduksi wanita. Pada ibu usia tua, ovum yang dikeluarkan pada saat ovulasi merupakan hasil dari oosit yang cenderung telah berada dalam siklus meiosis yang terhenti cukup lama.

Hasil penelitian ini menunjukan hubungan yang cukup lemah antara usia ibu dengan kejadian anak Sindrom Down di SLB Negeri Pelambuan Banjarmasin. Hal ini bisa disebabkan karena sifat dari responden penelitian dari kelompok anak tunagrahita yang memiliki beberapa faktor kesamaan berupa Retardasi Mental (RM) sehingga tidak terlihat signifikan pada hubungan usia ibu. Pendapat ini dikuatkan dengan hasil penelitian Hariyanto (2018) yang menyebutkan bahwa risiko mendapatkan bayi RM karena bertambahnya usia saat hamil, khusunya bagi ibu berusia lebih dari 35 tahun. Namun demikian, wanita hamil diusia muda tidak terlepas dari risiko mendapatkan bayi RM. Sejalan dengan hasil penelitian Huang et al (2016) menjelaskan bahwa meskipun tidak ada 
yang mengetahui secara pasti mengapa RM terjadi pada ibu berusia $\geq 35$ tahun namun para ilmuan mengetahui bahwa ibu tersebut akan memiliki risiko lebih tinggi melahirkan anak dengan RM.

Secara psikologis hampir semua anak dengan Sindrom Down memiliki kecerdasan dibawah 50 sehingga anak ini dikelompokan sebagai anak tunagrahita sedang (Alimin, 2004, disitasi oleh Leonard, 2018). Sejalan dengan Tarigan (2019) mendefinisikan bahwa tunagrahita merupakan suatu istilah yang digunakan pada anak yang memiliki perkembangan intelegensi yang lambat. Klasifikasi dari tunagrahita diukur berdasarkan tingkat IQ yang terbagi menjadi tiga kelas yaitu tunagrahita ringan, sedang dan berat.

Penyebab anak tunagrahita yang ditemukan berasal dari keturunan, gangguan metabolisme dan gizi, infeksi dan keracunan, trauma dan zat radioaktif, masalah kelahiran dan faktor lingkungan (Tarigan, 2019). Menurut Isdiyah (2018) dalam penelitiannya menyebutkan bahwa selain anak tunagrahita, ada juga anak tunagrahita dengan kelainan jasmaniah seperti Sindrom Down, Kretin (cebol), hydrocephal, microcephal, brahicephal dan scaphocephal.

Sel telur wanita telah terbentuk pada saat wanita tersebut masih dalam kandungan yang akan dimatangkan satu per satu setiap bulan pada saat wanita tersebut sudah dewasa. Oleh karena itu saat bertambahnya usia, kondisi sel telur terkadang menjadi kurang baik dan pada waktu dibuahi oleh sel sperma akan menyebabkan pembelahan yang kurang sempurna (Hariyanto, 2018). Sejalan dengan Irwanto, dkk (2019) menjelaskan bahwa terdapat dua cara pembelahan sel pada manusia yaitu mitosis (pembelahan sel biasa) dan meiosis (pembelahan sel yang terjadi dalam ovarium dan testis). Mitosis bekerja dengan membelah satu sel menjadi dua sel yang memiliki jumlah dan tipe kromosom yang sama persis dengan kromosom sel induk sedangkan meiosis terjadi pembelahan satu sel menjadi dua dengan jumlah kromosom setengah dari jumlah kromosom sel induk. Normalnya sel telur dan sel sperma hanya memiliki 23 kromosom sedangkan pada Sindrom Down 46 kromosom. Terdapat banyak kesalahan yang terjadi selama proses pembelahan sel. Pada proses meiosis, beberapa pasang kromosom membelah diri dan berpisah ke tempat yang berbeda sehingga disebut disjuction. Namun, kadang-kadang sel tidak membelah sehingga seseorang hanya memiliki 22 kromosom yang seharusnya 24 kromosom. Keadaan tersebut disebut nondisjunction dan dapat terjadi pada meiosis I dan II.

Wanita usia lebih dari 35 tahun lebih berisiko melahirkan bayi dengan Sindrom Down dibandingkan dengan ibu usia muda ( $<35$ tahun). Angka kejadian Sindrom Down pada usia ibu 35 tahun sebesar 1:400 kelahiran sedangkan ibu dengan umur kurang dari 30 tahun sebesar kurang dari 1:1000 kelahiran. Hal ini disebabkan oleh perubahan endokrin seperti peningkatan sekresi Androgen, penurunan kadar Hidroepiandrosteron, penurunan konsentrasi estradiolsistemik, perubahan konsentrasi reseptor hormon, peningkatan hormon LH (Luteinizing Hormone) dan FSH (Follicular Stimulating Hormone) secara mendadak pada saat sebelum dan selama menopause dapat meningkatkan kemungkinan terjadinya nondisjunction (Kemenkes RI, 2019).

\section{Hubungan Paritas Ibu dengan Kejadian Anak Sindrom Down di SLB Negeri Pelambuan Banjarmasin Tahun 2019}

Hasil analisis Uji korelasi Spearman Rank menggunakan nilai Sig. (2-tailed) sebesar 0,111 pada $\alpha 5 \%$ dengan $\mathrm{N}=98$ sehingga $p$ value $>0,05(0,111>0,05)$ maka Ho diterima sehingga tidak ada hubungan yang signifikan antara variabel paritas ibu dengan kejadian anak Sindrom Down di SLB Negeri Pelambuan Banjarmasin.

Berdasarkan hasil penelitian menunjukan bahwa kejadian anak dengan dan bukan Sindrom Down berasal dari paritas berisiko yaitu paritas 1 atau $\geq 4$. 
Hasil penelitian Pinontoan (2015) mengkalsifikasikan paritas menjadi berisiko (Paritas 1 dan $\geq 4$ ) dan tidak berisiko (paritas 2 dan 3). Hasil penelitiannya menunjukan paritas yang tinggi akan berdampak pada timbulnya berbagai masalah kesehatan baik bagi ibu maupun bayi yang dilahirkan. Kehamilan dan persalinan yang berulang-ulang menyebabkan kerusakan pembuluh darah didinding rahim dan kemunduran daya lentur (elastisitas) jaringan yang sudah berulang kali diregangkan kehamilan sehinga cenderung timbul kelainan letak ataupun kelainan pertumbuhan plasenta dan pertumbuhan janin sehingga melahirkan bayi berat badan lahir rendah.

Penelitian Neuhauser dan Krackow dari Institute of Medical Informatics, Biometry and Epidemiology di University Hospital Essen, Jerman bahwa bayi dengan Sindrom Down juga bergantung pada seberapa banyak saudara kandung dan seberapa besar jarak usia antara anak paling bungsu dengan bayi tersebut. Risiko memiliki bayi juga akan semakin meningkat bila jarak antara kehamilan semakin jauh. Risiko memiliki bayi dengan Sindrom Down pada ibu yang hamil untuk pertama kali diusia yang lebih tua (Kemenkes RI, 2019). Sejalan dengan penelitian Putri (2019) menjelaskan bahwa paritas 1 dan umur muda berisiko karena mental dan organ resproduksi wanita belum siap sedangkan paritas diatas 4 dan umur tua secara fisik mengalami kemunduran dalam menjalani kehamilan. Urutan kehamilan juga dapat dipengaruhi keadaan bayi yang akan dilahirkan. Hal ini terjadi karena pengaruh kondisi kesehatan ibu tersebut.

Hasil penelitian Anggeriyane (2014) yang menguatkan bahwa tidak adanya hubungan antara paritas ibu dengan kejadian anak Sindrom Down bahwa pada paritas 2 dan 3 tidak selalu melahirkan anak bukan sindrom down tetapi keadaan alat reproduksi yang sudah siap dibuahi sangat mempengaruhi kondisi kehamilan, keselamatan ibu dan janin misalnya jika jarak kehamilan terlalu dekat dengan kehamilan sebelumnya, maka akan banyak resiko yang menimpa baik ibu maupun janinnya. Rahim yang masih belum pulih benar akibat persalinan sebelumnya belum bisa memaksimalkan pembentukan cadangan makanan bagi janin dan untuk ibu sendiri. Akibatnya bayi akan terlahir dengan berat badan rendah, kekurangan zat gizi, asam folat sehingga bayi menjadi tidak sehat (Sindrom Down). Rahim yang diberikan jeda kehamilam akan mendapatkan cukup istirahat, cukup waktu untuk menyiapkan diri sehingga asupan nutrisi kepada bayi akan berjalan dengan baik dan pada akhirnya akan menjadikan bayi sehat dan berkualitas.

Berdasarkan teori tersebut peneliti menarik kesimpulan bahwa tidak hanya paritas yang menentukan risiko kejadian anak Sindrom Down tetapi pengaruh lebih besar berasal dari jarak anak sekarang dengan sebelumnya. Hal ini yang menyebabkan organ reproduksi wanita belum kembali pulih, begitu juga pada ibu usia tua dengan paritas tinggi sehingga organ reproduksi telah mengalami penurunan.

\section{Hubungan Usia Ayah dengan Kejadian Anak Sindrom Down di SLB Negeri Pelambuan Banjarmasin tahun 2019}

Hasil analisis Uji korelasi Spearman Rank menggunakan nilai Sig. (2-tailed) sebesar 0,192 pada $\alpha 5 \%$ dengan $\mathrm{N}=98$ sehingga $\mathrm{p}$ value $<0,05(0,192>0,05)$ maka Ho diterima artinya tidak ada hubungan antara variabel usia ayah dengan kejadian anak Sindrom Down di SLB Negeri Pelambuan Banjarmasin.

Menurut Kemenkes RI (2019) risiko Sindrom Down sekitar 3\% jika ayah adalah agen pembawa (carrier) dan 10$15 \%$ jika ibu adalah agen pembawa. Sejalan dengan Menurut Fadhli (2010) menjelaskan kromosom anak berasal dari bapak dan ibunya masing-masing atau separuh dari jumlah kromosom seluruhnya. Diduga Sindrom Down mendapat jumlah kromosom 23 dari bapak dan 24 dari ibu. Hal ini disebabkan oleh karena adanya pembelahan sel telur ibu yang tidak sempurna. Hasil penelitian Rahmah (2014) memperkuat dengan 
faktor lain yaitu usia ayah berisiko dapat mempengaruhi kejadian anak lahir dengan Sindrom Down. Kemungkinan tersebut karena salah satu keluarga memiliki resiko yang diturunkan pada suatu kelahiran.

Usia ideal laki-laki yang matang secara biologis dan psikologis adalah 2530 tahun berdasarkan ilmu kesehatan (BKKBN, 2017). Sejalan dengan Koran Republika (2018) yang memaparkan bahwa penelitian dari Stand Ford University School of Medicine mengemukakan bahwa usia seorang ayah meningkatkan risiko terhadap kelahiran bayi. Data yang menghubungkan kelahiran hidup bayi di Amerika Serikat (AS) dengan ayah yang berusia tua memiliki hubungan terjadinya peningkatan risiko kelahiran bayi. Bank sperma di AS pada umumnya memang menolak sperma dari pria yang berusia 40 tahun ke atas. Penelitian menyebut, kualitas sperma akan menurun seiring dengan usia. Walau penelitian di Inggris mengatakan dibanding sel sperma, usia wanita lebih berpengaruh pada terjadinya kehamilan (Koran Kompas, 2014).

Penelitian Anggeriyane

memaparkan pernyataan Bapak Genetika (George Mendel) tentang teori Hukum Mendel I (Hukum Segregasi) secara umum mencakup 3 pokok yaitu "gen memiliki bentuk alternatif yang mengatur variasi pada karakter keturunannya yang berhubungan dengan alel resesif (tidak selalu tampak dari luar) dan alel dominan (tampak dari luar), setiap individu membawa sepasang gen, jika sepasang gen ini merupakan dua alel yang berbeda maka alel dominan akan selalu terekspresikan (tampak secara visual dari luar) sedangkan alel resesif tidak selalu terekspresikan tetapi akan diwariskan pada gamet yang dibentuk oleh keturunannya".

Salah satu faktor yang dapat mempengaruhi kondisi bayi saat dilahirkan dan bagaimana perkembangannya berasal dari potensi genetisnya. Namun, pada kondisi tertentu terjadi penyimpangan genetik sehingga berefek negatif pada perkembangan kelahiran anak. Seorang anak yang mewarisi satu gen dari ayah dan satu gen dari ibu. Jika kedua gen yang diwariskan adalah gen normal maka anak akan normal tetapi jika salah satu atau kedua gen tidak normal maka anak akan sakit atau tidak normal. Salah satu penyimpangan genetik adalah Sindrom Down (Soetjiningsih, 2018).

Berdasarkan teori diatas, peneliti menarik kesimpulan bahwa kejadian anak dengan Sindrom Down tidak hanya dipengaruhi oleh satu faktor yang dominan seperti usia ayah tetapi faktorfaktor lain yang saling mendukung seperti genetik, faktor lingkungan, riwayat kelahiran anak sebelumnya dengan Sindrom Down dan usia ibu. Agen pembawalah yang mempengaruhi kelahiran pada generasi selanjutnya atau pembawa sifat pada kecacatan lahir seperti Sindrom Down.

\section{KESIMPULAN}

Kesimpulan penelitian ini adalah :

1. Usia ibu terbanyak saat melahirkan murid SLB Negeri Pelambuan Banjarmasin terdapat pada kategori usia tidak berisiko berjumlah 52 orang $(53,06 \%)$.

2. Paritas ibu terbanyak adalah paritas berisiko saat melahirkan murid SLB Negeri Pelambuan Banjarmasin berjumlah 61 orang $(62,24 \%)$.

3. Usia ayah terbanyak adalah tidak berisiko saat ibu melahirkan murid SLB Negeri Pelambuan Banjarmasin berjumlah 77 orang $(78,57 \%)$.

4. Kejadian Sindrom Down terbanyak adalah pada kategori bukan Sindrom Down adalah 92 orang $(93,8 \%)$.

5. Ada hubungan yang cukup lemah antara variabel usia ibu dengan kejadian anak Sindrom Down di SLB Negeri Pelambuan Banjarmasin.

6. Tidak ada hubungan yang signifikan antara variabel paritas ibu dengan kejadian anak Sindrom Down di SLB Negeri Pelambuan Banjarmasin.

7. Tidak ada hubungan yang signifikan antara variabel usia ayah dengan 
kejadian anak Sindrom Down di SLB Negeri Pelambuan Banjarmasin

Berdasarkan simpulan di atas maka dapat disarankan bahwa:

1. Bagi Tenaga Kesehatan

Diharapkan dapat memberikan penyuluhan dan pendidikan kesehatan tentang perencanaan kehamilan diusia produktif bagi pasangan usia subur maupun tidak dan pemeriksaan Ante Natal Care (ANC) serta sosialisasi untuk menghindari kehamilan berisiko.

2. Bagi Instansi Pendidikan

Diharapkan pada pihak instansi pendidikan dalam hal ini SLB Negeri Pelambuan Banjarmasin memberikan pengetahuan berupa seminar dan konseling kepada ibu-ibu siswa khususnya kelompok tunagrahita tentang angka resiko kejadian Sindrom Down dan perawatan serta bimbingan anak saat di lingkungan tempat tinggalnya, serta menerima keadaan anaknya dengan lapang dada.

3. Bagi Ibu

Diharapkan dalam menjalani kehamilan sebaiknya memperhatikan masa-masa kehamilan dengan mengkonsumsi makanan yang bergizi, menjaga kondisi fisik, psikologis dan menghindari stres serta teratur melakukan pemeriksaan rutin antenatal care di pelayanan kesehatan serta menghindari usia berisiko melahirkan anak Sindrom Down.

4. Bagi Peneliti Selanjutnya

Peneliti selanjutnya diharapkan dapat melanjutkan penelitian ini dengan variabel yang berbeda seperti riwayat penyakit ibu, genetik, riwayat abortus dan stres serta adanya perbandingan sampel anak sindrom down dan anak yang sehat fisik dan psikologis dengan menggunakan data primer dan observasi.

\section{ACKNOWLEDGMENT}

Terimakasih Kepada Kepala Sekolah SLB Negeri Pelambuan Banjarmasin dan Universitas Muhammadiyah Banjarmasin yang telah memberikan kesempatan untuk melaksanakan penelitian.

\section{DAFTAR PUSTAKA}

Anggeriyane, E., dkk. (2014). Hubungan Usia dan Paritas Ibu dengan Kejadian Anak Sindrom Down di SLB B/C Dharma Wanita Persatuan Provinsi Kalimantan Selatan di Banjarmasin. Healthy. Vol 3, No. 1, Juni 2014, ISSN No. 2301654X,Pp.17-24.

Anonim. (2017). Hebat, Anak-anak Penderita Down Syndrome Kalsel ini, Bisa menjadi Peniru dan Penghafal yang Kuat. Diakses pada tanggal 1 November 2019 dari https://banjarmasin.tribunnews.com/ 2017/11/27/hebat-anak-anakpenderita-down-syndrome-kalselini-bisa-menjadi-peniru-danpenghafal-yang-kuat

Anonim. (2019). Mendel's Law of Segregation (Internet). Diakses pada tanggal 1 November 2019 dari https://bio.libretexts.org/Bookshelve s/Introductory_and_General_Biolog y/Book\%3A_General_Biology_(Bo undless)/12\%3A_Mendel $\% 27$ s_Exp eriments_and_Heredity/12.3\%3A_L aws_of_Inheritance/12.3C $\% 3 \mathrm{~A} \_\mathrm{Me}$ ndel\%E2\%80\%99s_Law_of_Segreg ation

Astuti, R. Y. \&Ertiana, D. (2018). Anemia dalam Kehamilan. Jawa Timur: Pustaka Abadi.

BKKBN. (2017). BKKBN: Usia Pernikahan Ideal 21-25 Tahun. (Internet). Diakses pada tanggal 3 November 2019 dari https://www.bkkbn.go.id/detailpost/ bkkbn-usia-pernikahan-ideal-21-25tahun

Fadhli, A. (2010). Buku Pintar Kesehatan Anak. Yogyakarta: Pustaka Anggrek.

Hariyanto, D. (2018). Hubungan Antara Usia Ibu Saat Hamil dengan Terjadinya Sindrom Down. (Naskah Publikasi). Diakses pada tanggal 30 Oktober 2019 dari 
http://repositori.usu.ac.id/handle/123 456789/3860

Huang, J; Zhu, T; Gu, Y; Mu, D. (2016). Prenatal, Perinatal and Neonatal Risk Factors for Intellectual Disability: A Systemic Review and Meta Analysis.PloSone. 2016 Apr 25;11(4):e0153655. doi:

10.1371/journal.pone.0153655. eCollection 2016.

Isdiyah, S. (2018). Media Gambar Buah untuk Meningkatkan Prestasi Belajar Matematika tentang Penjumlahan Bagi Anak Tunagrahita Ringan Kelas III SDLBN Tamanwinangun Kebumen Tahun Pelajaran 2013/2014. Jurnal Pendidikan Konvergensi. Edisi 23/ Vol V/ Januari 2018. ISSN 23019050. CV. Akademika Bekerjasama dengan Litbang Pendidikan STIE AUB Surakarta. Pp. 153-164.

Irwanto, dkk. (2019). A-Z Sindrom Down. Surabaya: Airlangga University Press.

Kemenkes RI. (2019). Antara Fakta dan Harapan Sindrom Down. Infodatin. ISSN 2442-7659. Diakses pada tanggal 1 November 2019 dari https://pusdatin.kemkes.go.id/resour ces/download/pusdatin/infodatin/inf odatin-down-syndrom-2019.pdf

Koran Republika. (2018). Usia Ayah Ternyata Berisiko Terhadap Kelahiran Bayi (Internet). Diakses pada tanggal 3 November 2019 dari https://www.republika.co.id/berita/g aya-hidup/info-

sehat/18/11/06/phrcfa349-usia-ayahternyata-berisiko-terhadap-

kelahiran-bayi

Koran Kompas. (2014). Jadi Ayah di Usia 40 Tahun, Adakah Pengaruhnya pada Kesehatan Bayi?(Internet). pada tanggal 28 Oktober 2019 dari https://lifestyle.kompas.com/read/20 14/12/29/102004323/Jadi.Ayah.di.U sia.40.Tahun.Adakah.Pengaruhnya.p ada.Kesehatan.Bayi.

Mufidati, M. (2017). Sekolah Luar Biasa Tunagrahita di Bontang, Kalimantan Timur dengan Penekanan
Karakteristik Pengguna. Universitas Gadjah Mada. Skripsi. Diakses pada tanggal 27 Oktober 2019 dari http://etd.repository.ugm.ac.id/index .php?mod=penelitian_detail\&sub=P enelitianDetail\&act $=$ view\&typ $=$ htm $1 \&$ buku_id=132181\&is_local=1

Pinontoan, V. M., Tombokan, S. G. J. (2015). Hubungan Umur dan Paritas Ibu dengan Kejadian Bayi Berat Lahir Rendah. Jurnal Ilmiah Bidan Vol. 3, No. 1 (2015). ISSN: 23391731. Pp. 20-25.

Putri, A. W., Pratitis, A., Luthfiya, L., Wahyuni, S., \& Tarmali, A. (2019). Faktor Ibu terhadap Kejadian Bayi Berat Lahir Rendah. Higeia 3(1) (2019). P ISSN 1475-362846. E ISSN 1475-222656. Pp. 55-62.

Rahmah, H. N. (2014). Faktor-Faktor yang Mempengaruhi Terjadinya Down Syndrome. Universitas Muhammadiyah Surakarta. Naskah Publikasi.

Rayman, R., Rahmanisa, S. \& Putri, T. G. (2017). Hubungan Usia Ibu dengan Kejadian Sindrom Down. Medula. Vol 7, No. 5, Desember 2017. Pp. 144-148.

Soetjiningsih, C. H. (2018). Seri Psikologi Perkembangan: Perkembangan Anak Sejak Pembuahan sampai dengan Kanak-Kanak Akhir. Edisi Ketiga. Jakarta: Kencana.

Tarigan, E. (2019). Efektivitas Metode Pembelajaran Pada Anak Tunagrahita di SLB SiborongBorong. Jurnal Pionir LPPM Universitas Asahan Vol. 5 N0.3 Juli-Desember 2019, P-ISSN: 25493043, E-ISSN: 2655-3201. Pp. 5662 
Jurnal Keperawatan Suaka Insan| Vol.4 Ed.2 Desember 2019 